\title{
The Use of SST Anomaly to Predict Seasonal Rainfall during the Second Planting Period in the Tanoh Abee Irrigation Area, Aceh Besar
}

\author{
Ahmad Farhan ${ }^{1}$, Yopi Ilhamsyah ${ }^{2}$, Akhyar ${ }^{3}$ \\ ${ }^{1}$ Department of Physics Education, Faculty of Teacher Training and Education Science. University of Syiah Kuala, Banda Aceh, \\ Indonesia, 23111 \\ ${ }^{2}$ Department of Marine Sciences, Faculty of Marine and Fisheries. University of Syiah Kuala, Banda Aceh, Indonesia, 23111 \\ ${ }^{3}$ Department of Mechanical Engineering, Faculty of Engineering. University of Syiah Kuala, Banda Aceh, Indonesia, 23111
}

\section{ARTICLE INFO}

\section{Received}

30 October 2019

\section{Revised}

10 February 2020

\section{Accepted for Publication \\ 13 August 2020}

\section{Published}

30 September 2020

doi: 10.29244/j.agromet.34.2.100-109

\section{Correspondence:}

Ahmad Farhan

Department of Physics Education, Faculty of Teacher Training and Education Science. University of Syiah Kuala, Banda Aceh, Indonesia, 23111. Email: farhan@unsyiah.ac.id

This is an open-access article distributed under the CC BY License. (C) 2020 The Authors. Agromet.

\begin{abstract}
A B S T R A C T
Irrigation in Tanoh Abee is used for agricultural activities especially during the second planting season during dry season. However, the availability of irrigation water is controlled by total rainfall received. An accurate prediction of rainfall, which traditionally used "keneunong" local wisdom, is urgently required. The objective of the study is to obtain the best predictor of seasonal rainfall based on the Pacific sea surface temperature (SST) anomaly and the monthly lead time of prediction. We employed monthly rainfall from six stations surrounding the study area and combined with principal component analysis to eliminate rainfall autocorrelation. Seasonal rainfall (quarterly average) was calculated from monthly data. The results showed that 1-month lead time strongly correlated to seasonal rainfall in Tanoh Abee $(r<-0.7, \alpha=5 \%)$ for the second planting period. On other hand, the 2-month and 3-month lead time were useful to predict seasonal rainfall in March-April-May (MAM) only. For April-May-June (AMJ) and May-June-July (MJJ), the correlation between SST anomaly and seasonal rainfall was weak. This finding indicated that the accuracy of prediction decreases with the longer lead time. Based on our analysis, coordinates of $170^{\circ} \mathrm{E}-175^{\circ} \mathrm{E} ; 5^{\circ} \mathrm{N}-5^{\circ} \mathrm{S}$ in Niño 4 region have strongly correlated with seasonal rainfall in MAM, AMJ, and MJJ periods. Moreover, further research is necessary to combine any approaches that will improve our prediction skill for another 2- or 3-month lead time.
\end{abstract}

\section{KEYWORDS}

lead time, Niño region, prediction, sea surface temperature, spatial correlation

\section{INTRODUCTION}

The Tanoh Abee irrigation area is one of the technical irrigation rice fields located in Aceh Besar District, Aceh Province. The cropping pattern in the irrigated area was planned for rice-rice-fallow (Evariani, 2018). The first planting season takes place in the rainy season period from October to February. The second planting season takes place in the dry season period from March to July. During dry season, irrigation water discharge is low leading to water stress in rice plants (Chinwendu et al., 2017). This is the case for rice fields in the downstream area (rice fields in Darussalam District, Aceh Besar), where irrigation water is less than the crop water requirement during the second planting season (Bolota et al., 2016; Farhan and Wardah, 2014). To minimize the worst impacts of low irrigation water, an accurate rainfall prediction may benefit to provide information on water availability (Deo et al., 2017; Nurdiansyah and Faqih, 2018). Therefore, it may reduce the risk of water stress. Generally, there is a local wisdom called as "keuneunong" that is practiced as an ancestral heritage in Tanoh Abee irrigation area, Aceh. Although the keuneunong system has been practiced for long period to predict seasonal rainfall, the results of prediction are less accurate, especially during extreme climate events. 
Future climate conditions is unpredictable and will be more complex (Zhao and Li, 2015). Climate change worsened the climate condition by changes the rainfall intensity (Jadmiko and Faqih, 2014) and river discharge (Birkinshaw et al., 2017; Zhao et al., 2015). Current system in Aceh (keuneunong system) is not appropriate to generate a reliable prediction especially in changing climate. Therefore, climate prediction system based on scientific standard with high accuracy is urgently required. This research is one step to initiate the development of seasonal rainfall prediction in Tanoh Abee irrigation area, particularly for the second planting period in dry season. At this stage, the research was performed to obtain the valid predictors for seasonal rainfall prediction model in the area.

The climate in Indonesia is influenced by global phenomenon (Misnawati and Perdanawanti, 2019), such as changes in sea surface temperature (SST) (Kim et al., 2019; van den Besselaar et al., 2017; Zhang et al., 2017) and Madden Julian Oscillation (Kosovelj et al., 2019; Lestari et al., 2019). SST has a strong effect on rainfall in Indonesia from the dry season to the transitional season, between April - November (Hidayat and Ando, 2014). Fluctuation of sea surface temperature in the Niño 3, 3.4, and 4 region will affect rainfall in Indonesia (Yananto and Dewi, 2016), such as rainfall in Central Java (Hidayat et al., 2018), West Java (Nabilah et al., 2017), Banten (Mulyaqin, 2020), Sulawesi (Prasetyo and Pusparini, 2018), and Sumatra (Qalbi et al., 2017). More specifically, the rainfall in Banda Aceh City and Aceh Besar District is also related to the variability of the Pacific sea surface temperature both in normal and extreme climate conditions (Ilhamsyah et al., 2019). Previous research mentioned that there was a relationship between the Pacific sea surface temperature anomaly for the period of March-April-May (MAM) and June-July-August (JJA) and the seasonal rainfall in the Aceh Besar, Aceh Province (Farhan and Wardah, 2014). Based on their work, we will use the SST anomaly as a predictor to predict seasonal rainfall for the second planting season (March-July) in the study area.

This research aims to reveal the following questions: (i) how many months ahead the predictor can predict the seasonal rainfall of the Tanoh Abee irrigation area for the second planting season? and (ii) in which coordinate of the SST predictor accurately predict seasonal rainfall? In the end, the research will obtain the best predictor that is used as input of seasonal rainfall prediction model in the study area.

\section{RESEARCH METHODS}

\section{Study Area}

The location of study was in the Tanoh Abee irrigation area, Aceh Besar District, Aceh Province (Figure 1). The irrigation area is integrated with other irrigation areas in Krueng Jreu, Krueng Aceh, and Keuliling Reservoir. The community surrounding the Tanoh Abee irrigation area does not use irrigation water for domestic or livestock/fisheries. Most irrigation water is used for rice, both during the first and the second planting seasons. Other crops such as palawija and horticulture are not popular as agricultural commodities in this irrigation area. The first planting season takes place in October-February, while the second planting season is in March-July. The water source for irrigation is tapped from the Tanoh Abee dam, in

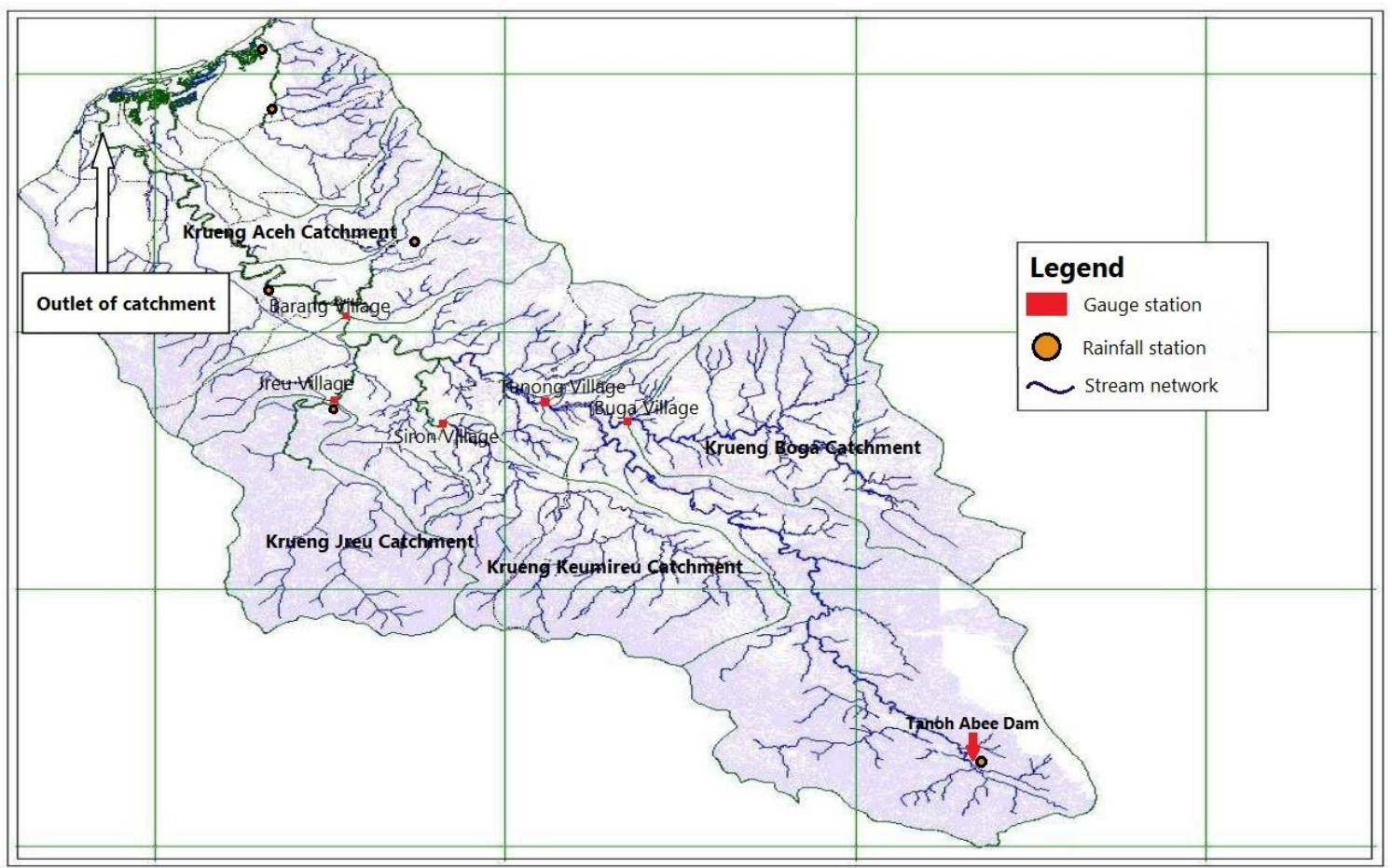

Figure 1. Map of Research Study in Aceh Besar District, Aceh Province (Nasrullah and Kartiwa, 2010) 
Seunebok Kemukiman Tanoh Abee Village, Aceh Besar. The water availability in the dam fluctuates following rainfall pattern, namely abundant water during rainy season and less water during dry season.

\section{Data}

This study used monthly rainfall data and the anomaly of SST from Pacific Ocean. The monthly rainfall was from six stations spreading the irrigation area namely Blang Bintang, Kuta Raja, Ule Kareng, Sibreh, Seulimum, and Indrapuri for the period 1990-2005 (16 years). On other hand, the SST anomaly for the period 1990 - 2005 (1 degree resolution) was accessed from https://www.esrl.noaa.gov/psd/gcos wgsp/Timeseries/ Data/nino.long.anom.data. The SST was grouped into four regions as shown in Figure 2.

\section{Data Analysis}

The second planting season in the Tanoh Abee irrigated area takes place in March-July. The rainfall was averaged on seasonal scale namely (a) March-AprilMay (MAM), (b) April-May-June (AMJ), and (c) MayJune-July (MJJ). The average seasonal rainfall was analyzed using the principal component analysis (PCA) technique to produce a new variable known as orthogonal principal component (PC) (van Delsen et al., 2017). Based on PCA analysis, PC1 was able to explain the diversity of data (Purnama, 2019; Rufaidah and Effindi, 2017) as indicated by the highest eigenvalue (76\%). Therefore, PC1 met the requirements for spatial correlation analysis, while other PCs were ignored because of their relatively small value. The data analysis followed diagram in Figure 3.

The spatial correlation between the Pacific SST anomaly (predictor) and the average seasonal rainfall of the Tanoh Abee irrigation area (predictands) was processed using the NCAR command language (NCL) software. We proposed lead time between the predictors and predictands as follows:

a. 1-month lead time, which is a prediction of rainfall one month ahead based on SST anomaly.

b. 2-month lead time, which is a prediction of rainfall two months ahead based on SST anomaly. c. 3-month lead time, which is a prediction of rainfall three months ahead based on SST anomaly.

The choice of Niño region as a predictor was based on their performance as indicated by correlation coefficient $(r \leq-0.7)$. The region then was used as a predictor for the seasonal rainfall in the Tanoh Abee irrigation area for the second planting season.

\section{RESULTS AND DISCUSSIONS}

\section{Rainfall in Irrigation Area Tanoh Abee}

The average value of monthly rainfall from six stations (Blang Bintang, Kuta Raja, Ule Kareng, Sibreh, Seulimum, and Indrapuri) in the Tanoh Abee irrigation area is shown in Figure 4. The maximum rainfall occurs in November ( $>200 \mathrm{~mm}$ ), whereas the driest month is in July $(\sim 50 \mathrm{~mm})$. In period of June-August, monthly rainfall is less than $100 \mathrm{~mm}$ each. Typically, the climate type of the irrigation area is type $\mathrm{E}$ based on Oldeman's classification (consecutive wet months of less than three months).

For the second planting season, phases of rice cultivation are as follows: (a) tillage and seeding phases in March; (b) the vegetative and reproductive phases in April-June; and (c) the seed ripening phase in July. The first two phases are periods with high demanding water On other hand, the last phase does not require a lot of water, even irrigation is not needed when the rice plant is in the yellow maturity (Fuadi et al., 2016). From the observed rainfall distribution, the tillage, vegetative, and reproductive periods of the second planting season occur in the transition from wet to dry months (rainfall $<200 \mathrm{~mm}$ ), therefore, there is still chance of drought in rice cultivation.

\section{Spatial Correlation}

Spatial correlation between the SST anomaly in the Pacific Ocean with the average seasonal rainfall during the MAM period for the 1-month lead time prediction is shown in Figure 5a. A high spatial correlation ( $r<-0.7$; at significant level $\alpha=5 \%$ ) was indicated at coordinates $160^{\circ} \mathrm{E}-180^{\circ} \mathrm{E} ; 5^{\circ} \mathrm{S}-5^{\circ} \mathrm{N}$ (red box, Figure 5). Location outside the Niño region were ignored even though they have a high spatial correlation value. Previ-

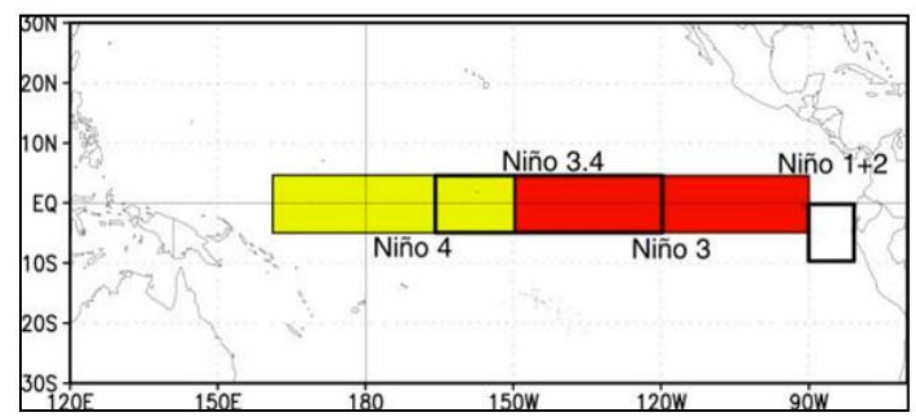

Figure 2. Niño regions in the Pacific Ocean, where monthly SST anomalies were derived in the Niño 3, 3.4, and 4 regions ( $\left.160^{\circ} \mathrm{E}-120^{\circ} \mathrm{W} ; 5^{\circ} \mathrm{LS}-5^{\circ} \mathrm{LU}\right)$ as input data (https://www.cpc.ncep.noaa.gov/). 


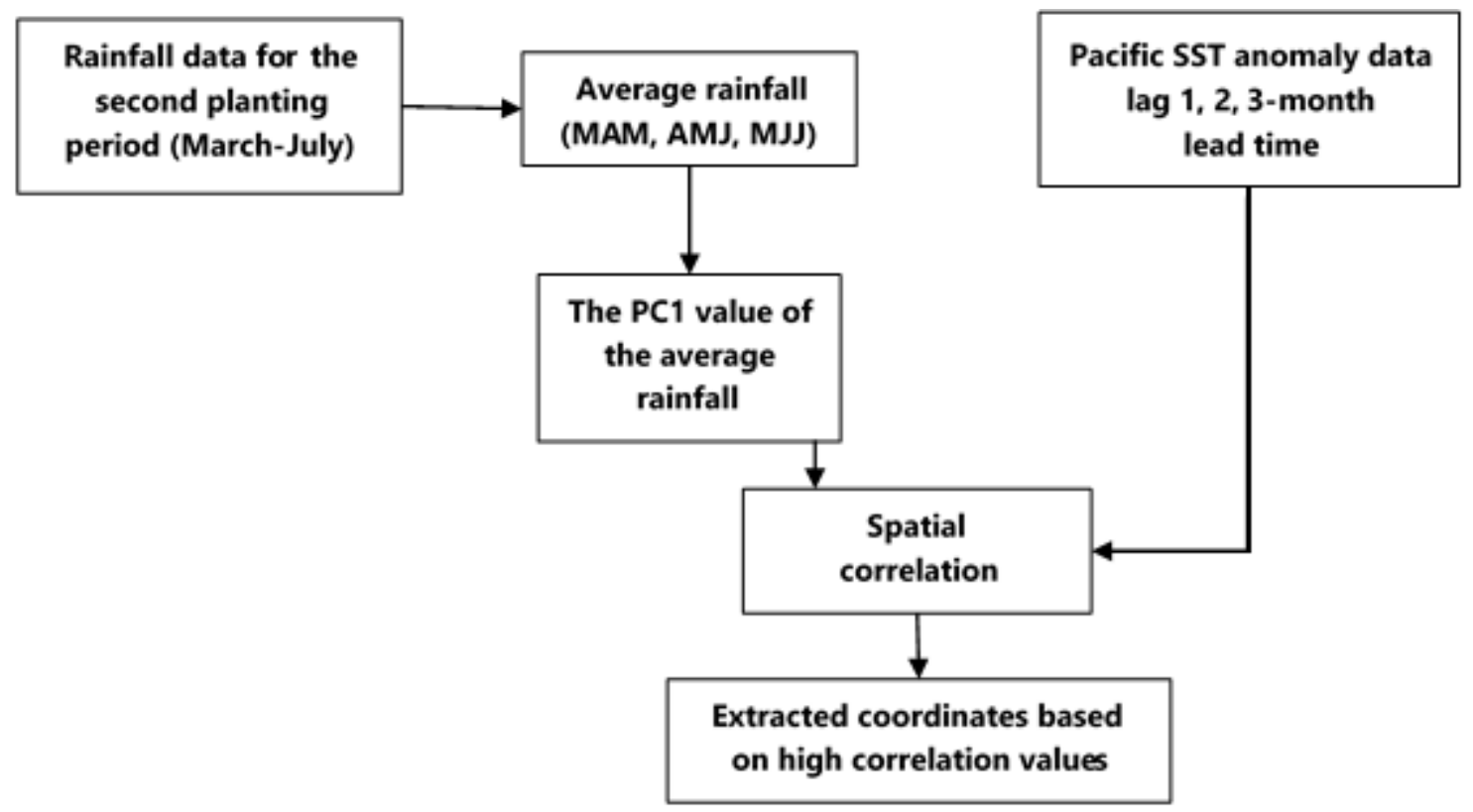

Figure 3. The stages of research data analysis

ous researches revealed that the Niño region may affect the rainfall variability in Indonesia (Hidayat et al., 2018; Nabilah et al., 2017; Pan et al., 2018; Qalbi et al., 2017; Yananto and Dewi, 2016). Therefore, the predictor coordinates were only taken in the Niño region. To predict seasonal rainfall at MAM period, the February SST anomaly at coordinates $160^{\circ} \mathrm{E}-180^{\circ} \mathrm{E} ; 5^{\circ} \mathrm{S}-5^{\circ} \mathrm{N}$ was used.

For the 2-month lead time, the correlation was also high and spatially the same as the 1-month lead time (Figure 5b). Even though the coordinates are the same, the spatial correlation coefficient values were different i.e. -0.8 and -0.7 for 1 -month lead time and 2month lead time analysis. For the 3-month lead time, the correlation was smaller (Figure $5 \mathrm{c}$ ). The results indicated that the prediction accuracy decreases with the increased lead time. For the AMJ period, the spatial correlation is presented in Figure 6.
The SST anomaly in March was used to predict the average seasonal rainfall in the AMJ period (1month lead time). High correlation was obtained at coordinates $165^{\circ} \mathrm{E}-175^{\circ} \mathrm{E}$ dan $5^{\circ} \mathrm{S}-5^{\circ} \mathrm{N}$ (Figure 6a). The red box mark in Figure 6 indicates the coordinate with high correlation $(r<-0.7)$. Compared to MAM period, the area of the spatial correlation coordinates for the average AMJ seasonal rainfall is relatively smaller. Figure $6 \mathrm{~b}$ shows the spatial correlation between the SST anomaly in February and the predicted seasonal rainfall in AMJ (2-month lead time). Clearly the relationship between SST anomaly and rainfall for AMJ was not significant $(r \simeq-0.4)$, and only few coordinates have high correlation. Similarly, the 3-month lead time to predict seasonal rainfall in AMJ period was no high correlation (Figure $6 c, \alpha=5 \%$ ). The findings revealed that both the 2-month and 3-month lead time were not

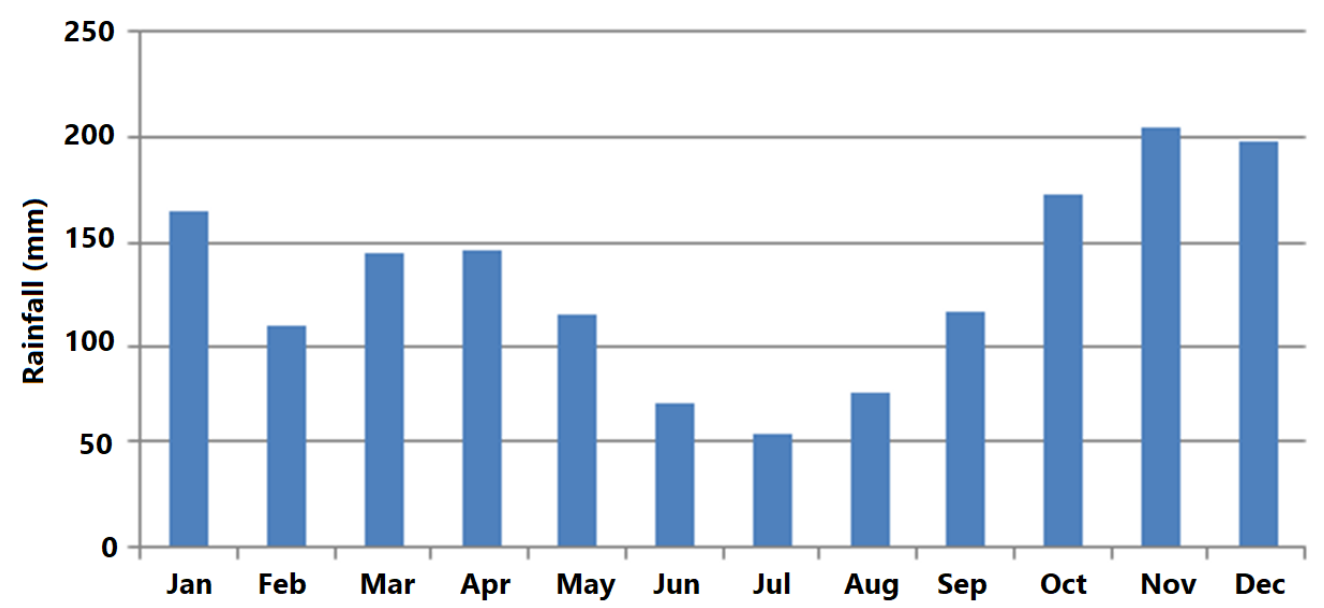

Figure 4. Average monthly rainfall $(\mathrm{mm})$ based on six observation stations in the Tanoh Abee irrigation area, Aceh Besar District. The data used is for 1990-2005. 

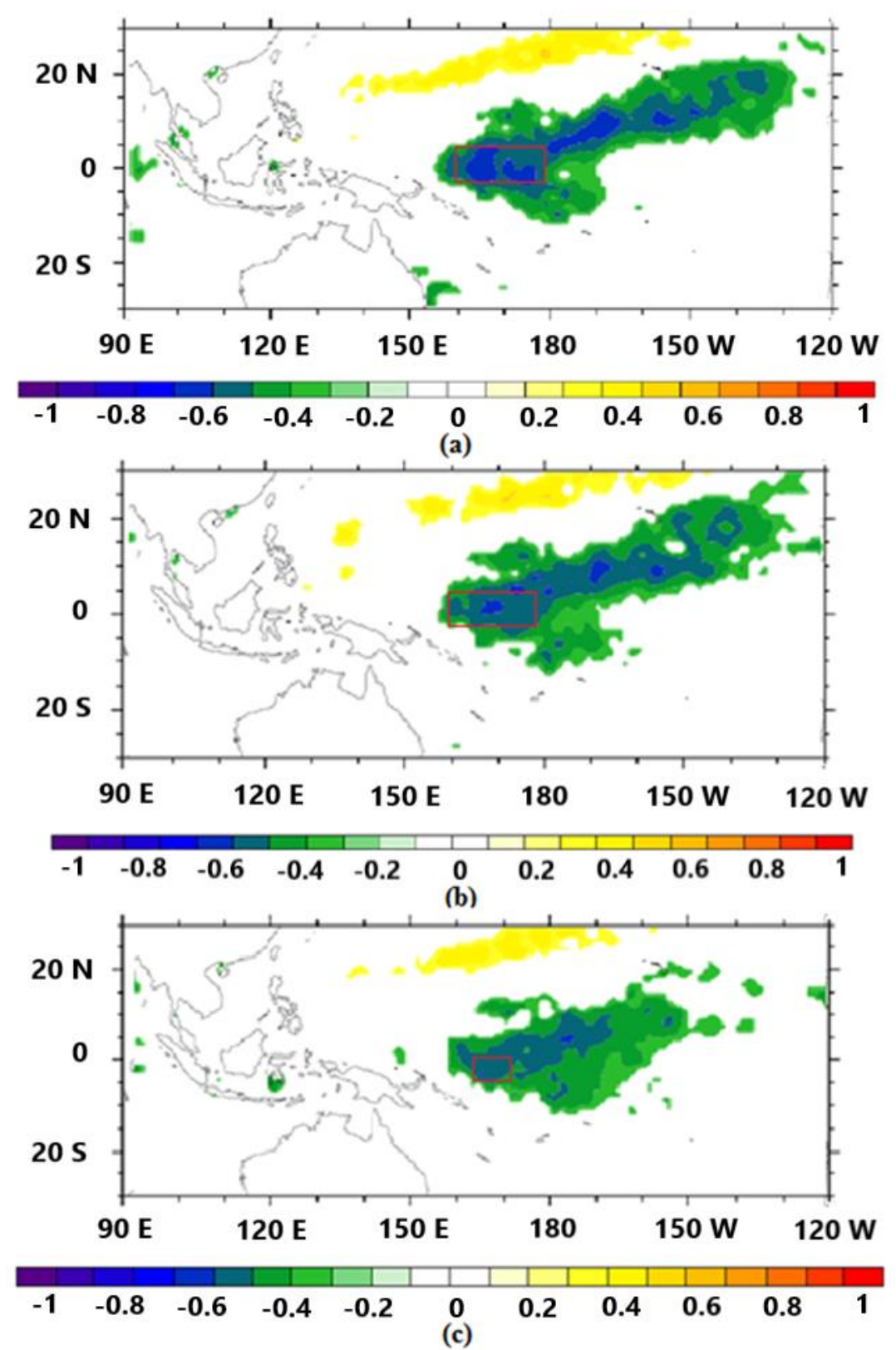

Figure 5. The spatial correlation between SST anomaly at Pacific Ocean with the average seasonal rainfall in the MAM period: (a) February (1-month lead time), (b) January (2-month lead time), and (c) December (3-month lead time). The prediction was applied in Tanoh Abee irrigation area.

accurate to predict the average seasonal rainfall of the Tanoh Abee irrigation area for AMJ period. Thus, only the SST Pacific anomaly in March was promising as a predictor of the mean seasonal rainfall of the Tanoh Abee irrigation area for the AMJ period.

Then we analyzed the accuracy of predictor in MJJ period. Figure 7 shows the correlation between SST anomaly parameters and the seasonal rainfall of the Tanoh Abee irrigation area in the MJJ period. For 1month lead time, coordinates Niño $170^{\circ} \mathrm{E}-180^{\circ} \mathrm{E} ; 5^{\circ} \mathrm{S}$ $-5^{\circ} \mathrm{N}$ (red box, Figure 7a) indicate strong correlation $(r<-0.7, \alpha=5 \%)$ between the predictor and the predictand. Compared to AMJ period, the coordinates having strong correlation is smaller (see Figure 6a).

Figure $7 \mathrm{~b}$ shows the spatial correlation between the SST anomaly in March and the predicted seasonal rainfall in MJJ (2-month lead time). Most coordinates for Niño region show having weak correlation $(r \simeq-0.4)$, and only small proportions have high correlation. The result indicated that the 2-month lead time SST anomaly was not good as a predictor for rainfall in MJJ period. The 3-month lead time also resulted in a weak correlation (Figure $7 c, \alpha=5 \%$ ) to predict seasonal rainfall in MJJ period. Like AMJ period, the results revealed that both the 2-month and 3-month lead time were not accurate to predict the average seasonal rainfall for MJJ period. Thus, the results confirmed that the 1-month lead time was promising as a predictor of the mean seasonal rainfall of the Tanoh Abee irrigation area for the AMJ and MJJ period.

Based on the spatial correlation between the predictor parameters (SST anomaly in the Pacific Oce- 


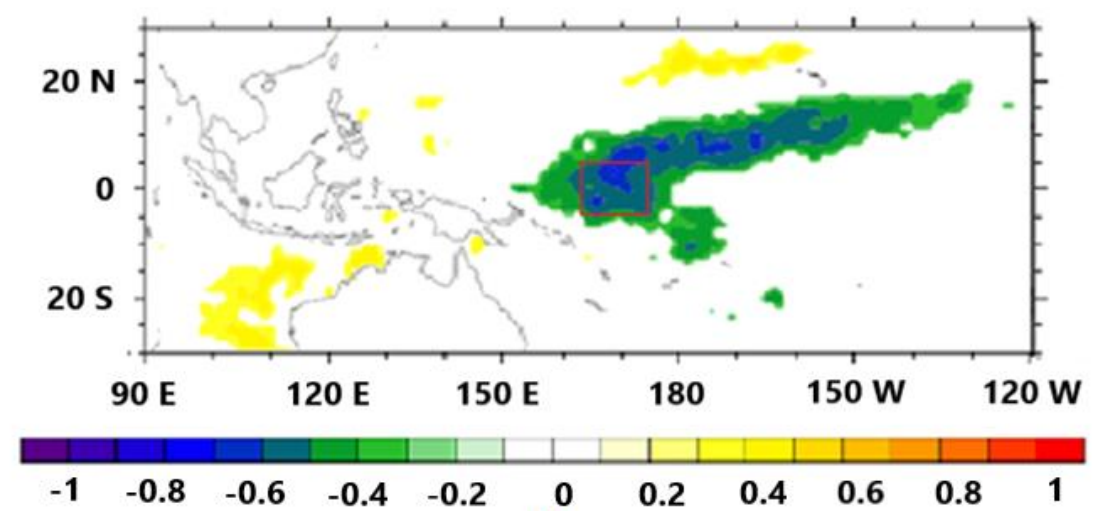

(a)

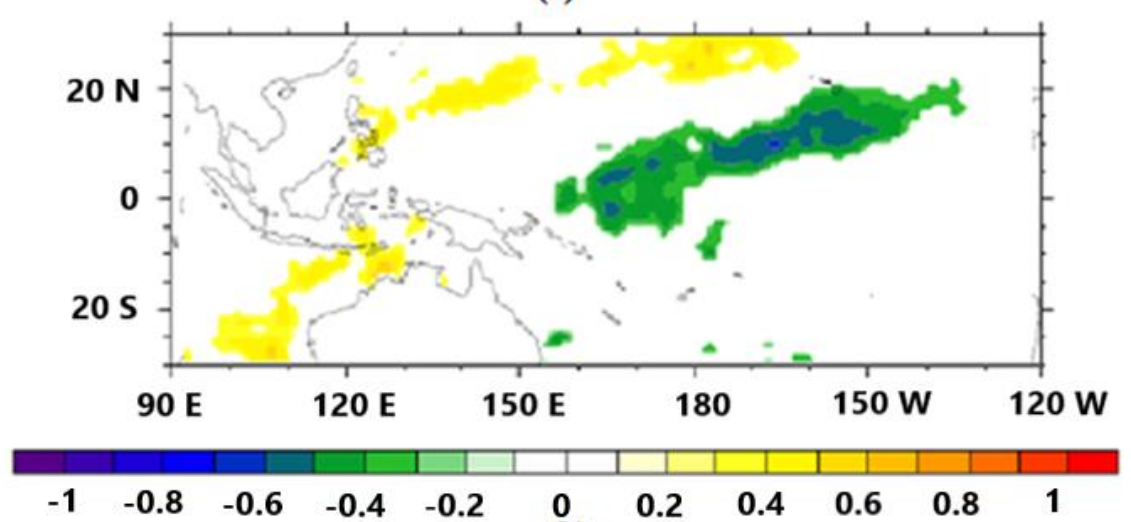

(b)

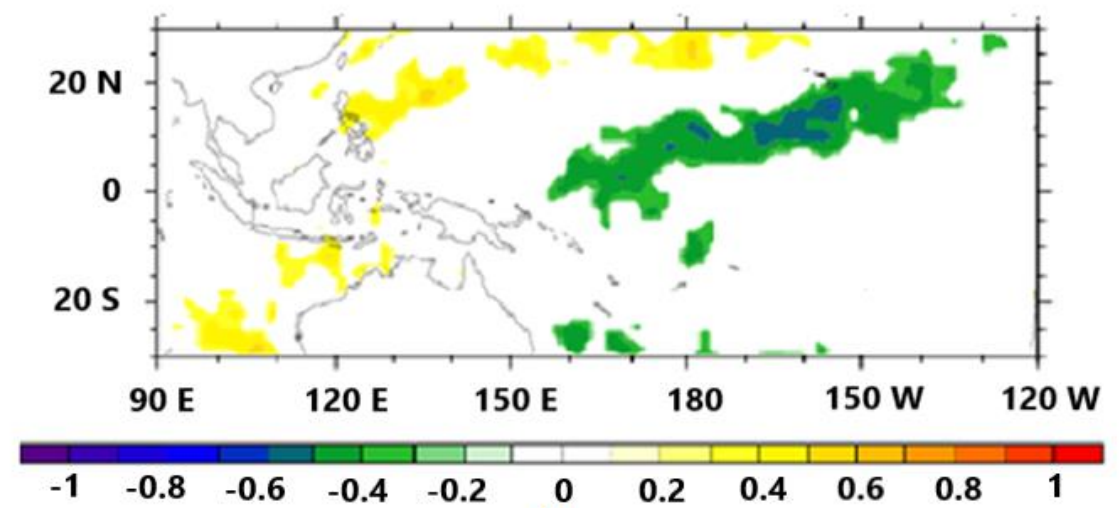

(c)

Figure 6. The spatial correlation between SST anomaly at Pacific Ocean with the average seasonal rainfall in the AMJ period: (a) March (1-month lead time), (b) February (2-month lead time) and (c) January (3-month lead time). The prediction was applied in Tanoh Abee irrigation area.

an) and the predictand (average seasonal rainfall of the Tanoh Abee irrigation area for the second planting season), a strong correlation coefficient ( $r<-0.7 ; \alpha=5 \%)$ was obtained for the MAM period with the 1-, 2-, and 3-month lead time SST anomaly. Meanwhile, for the AMJ and MJJ periods, a strong correlation was only observed on the 1-month lead time. Based on this result, the accuracy of the prediction is low if we used the longer lead time. Our findings confirmed previous researches that SST anomalies control the rainfall variability for the second growing season (March-July). For instance, SST anomalies affected the rainfall variability in the northern coast of Aceh Province (Farhan and Wardah, 2014), especially the city of Banda Aceh and Aceh Besar (Ilhamsyah et al., 2019).

\section{Predictands Coordinates}

The coordinates of the Niño Region which have strong correlation $(r \leq-0.7)$ between the SST anomaly and the average seasonal rainfall of the Tanoh Abee irrigation area in the second planting season are listed in Table 1. All the coordinates are in Niño Region 4. The finding is consistent with the previous researches that shows the rainfall variability in Indonesia under normal climate conditions is related to the variation in sea surface temperature in the western Pacific (Windari et al., 2012). Therefore, the coordinates of SST anomaly that obtained from this study was used as locations to extract the predictor. However, other researches showed that for extreme climatic conditions, rainfall anomalies 


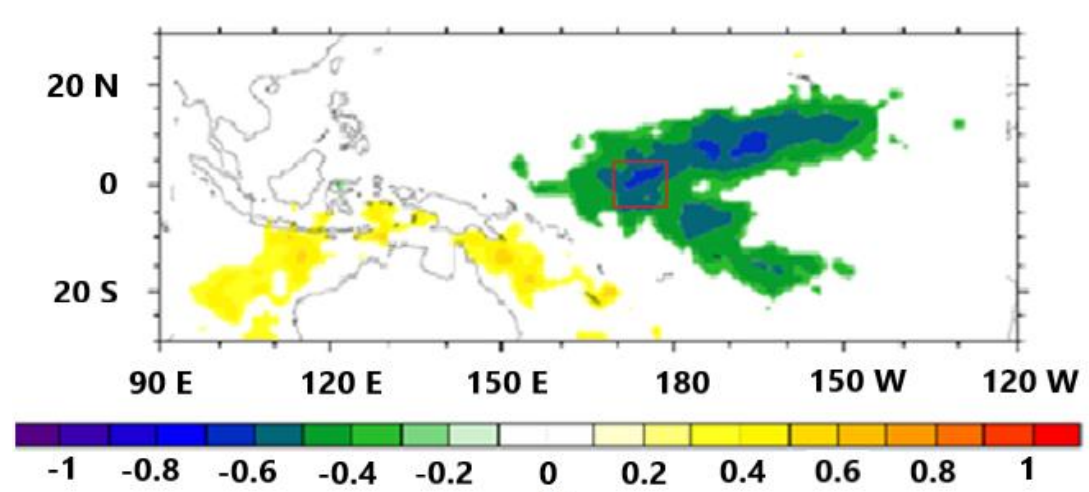

(a)

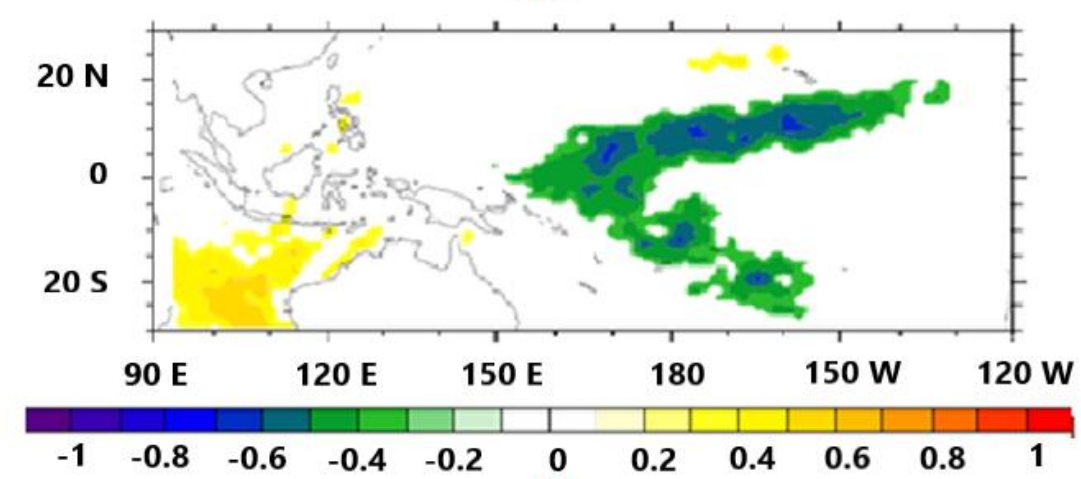

(b)

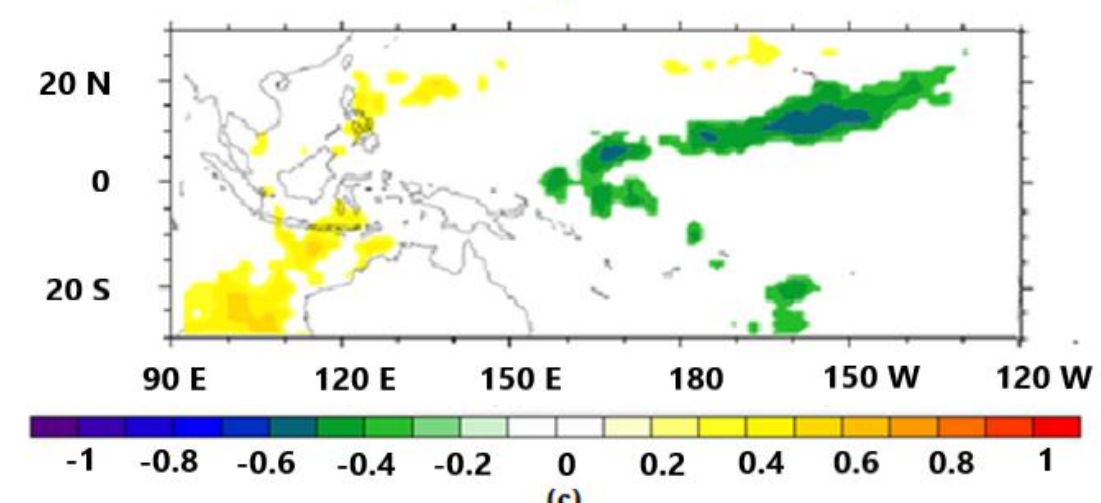

(c)

Figure 7. The spatial correlation between SST anomaly at Pacific Ocean with the average seasonal rainfall in the MJJ period: (a) April (1-month lead time), (b) March (2-month lead time), and (c) February (3-month lead time). The prediction was applied in Tanoh Abee irrigation area.

in Indonesia in the Monsoon climate are generally associated with the Pacific SST anomaly in the Niño region 3.4 (Hidayat et al., 2018; Prasetyo and Pusparini, 2018).
Table 1 indicates different coordinates of the Niño region that have strong correlation in predicting seasonal rainfall. The difference is caused by climate type of the study area. Likely, the Tanoh Abee belongs

Table 1. Coordinates of the Pacific Ocean, which the sea surface temperature anomaly was extracted to predict seasonal rainfall. All coordinates were located at Niño 4 region that have a strong correlation $(r<-0.7, \alpha=5 \%)$ with seasonal rainfall in the second growing season

\begin{tabular}{cccc}
\hline Season & Monthly Lead Time & Pacific Ocean Coordinates & r Value \\
\hline \multirow{3}{*}{ MAM } & 1 & $160^{\circ} \mathrm{E}-180^{\circ} \mathrm{E} ; 5^{\circ} \mathrm{S}-5^{\circ} \mathrm{N}$ & $-0.8--0.7$ \\
\cline { 2 - 4 } & 2 & $160^{\circ} \mathrm{E}-180^{\circ} \mathrm{E} ; 5^{\circ} \mathrm{S}-5^{\circ} \mathrm{N}$ & $-0.8-0.7$ \\
\hline \multirow{3}{*}{ AMJ } & $165^{\circ} \mathrm{E}-170^{\circ} \mathrm{E} ; 5^{\circ} \mathrm{S}-5^{\circ} \mathrm{N}$ & $-0.8--0.7$ \\
\cline { 2 - 4 } & 1 & $165^{\circ} \mathrm{E}-175^{\circ} \mathrm{E} ; 5^{\circ} \mathrm{S}-5^{\circ} \mathrm{N}$ & $-0.8--0.7$ \\
\hline \multirow{2}{*}{ MJJ } & 2 & - & - \\
\cline { 2 - 4 } & 3 & - & $-0.8--0.7$ \\
\hline & 1 & $170^{\circ} \mathrm{E}-180^{\circ} \mathrm{E} ; 5^{\circ} \mathrm{S}-5^{\circ} \mathrm{N}$ & $-0.8--0.7$ \\
\hline
\end{tabular}


to semi monsoonal climate (Ilhamsyah et al., 2019). For the extreme rainfall, the variability of rainfall was associated with Niño 3.4 Region, especially for monsoonal climate (Hidayat et al., 2018; Prasetyo and Pusparini, 2018). Other possibility that trigger the difference is the period data used. Here we use an average rainfall of 16 years (1990-2005) in the Tanoh Abee irrigation area. This data consists of rainfall in normal and extreme climate. Therefore, we suggest to organizing the rainfall data based on those climate condition. The rather short data (less than 20 years) may not properly describe the state of rainfall under extreme climates, which occur on long-term climate period. Based on this consideration, it is necessary to analyze rainfall data based on normal and anomalous climates. Then we will obtain the extracted coordinates of SST anomaly to predict seasonal rainfall both for normal and extreme climate.

With the SST anomaly, the predictors can predict seasonal rainfall in the Tanoh Abee irrigation area for the second planting season up to 3 months ahead for the MAM period. On other hand, the SST anomaly was only able to predict for 1 month ahead during the AMJ and MJJ periods. Therefore, the distance between the predictors and predictand is set one month ahead (1month lead time). Table 1 indicates that there are different coordinates of the region that are used to predict rainfall especially for 1-month lead time. Therefore, we assumed the coordinates of $170^{\circ} \mathrm{E}-175^{\circ}$ $\mathrm{E} ; 5^{\circ} \mathrm{N}-5^{\circ} \mathrm{S}$ as locations for predictor. We extracted the SST anomaly from the coordinates to predict seasonal rainfall in Tanoh Abee irrigation area.

\section{DISCUSSIONS}

Study on climate related to water resources in Aceh Province is limited especially in the Tanoh Abee irrigation area. This irrigation area support food sustainability in Aceh Besar and Banda Aceh City. Any climate related disaster in this area will affect to food stability and farmers' losses, therefore, research and assessment on rainfall variability impacts is necessary. The result of assessment will benefit as information to mitigate climate related disaster especially in the cultivation system in the Tanoh Abee irrigation area.

One study revealed that SST anomalies in the Pacific Ocean influence rainfall variability in the northern coastal climate area of Aceh Province (Farhan and Wardah, 2014). Their work did not count lead time prediction, namely in the same time (0-month lead time). Here we improved their approach by introducing lead time prediction of seasonal rainfall in the Tanoh Abee irrigation area. Our finding showed that 1-month lead time is promising to rainfall prediction based on global output from SST.
The study has a limitation namely short-term prediction of 1-month lead time for rainfall. The SST anomaly of Nino 4 region has strong correlation with average seasonal rainfall one month ahead. This finding may not sufficient because crop planning and management are generally carried out at least two months before the planting period takes place. Further research is still challenging to combine other variables that affect to rainfall variability in the Tanoh Abee irrigation area. The use of SST from Indian Ocean may improve the skill prediction of our approach. Previous researches indicated that Indian Ocean Dipole (IOD) influence crop failure in tropics (Anderson et al., 2019) and Southeast Asia (Gao et al., 2019). The crop failure is related to extreme rainfall associated with IOD (Hendrawan et al., 2019; Krishnaswamy et al., 2015). Hopefully, further research can obtain a new predictor to forecast seasonal rainfall in study area for the second planting season for the 2and 3-month lead time.

\section{CONCLUSIONS}

Seasonal rainfall of the Tanoh Abee irrigation area associates with the SST anomaly in Pacific Ocean. Our result showed that Niño 4 region has strong correlation with seasonal rainfall in MAM, AMJ, and MJJ periods. Specifically, coordinates of $170^{\circ} \mathrm{E}-175^{\circ} \mathrm{E} ; 5^{\circ}$ $\mathrm{N}-5^{\circ} \mathrm{S}$ was used to extract the SST anomaly. For the second planting time, our model is able to predict rainfall with one-month lead time only. Therefore, further research is necessary to combine any approaches that will improve our prediction skill for another two- or three-month lead time.

\section{ACKNOWLEDGEMENT}

We acknowledge to the Institute of Research and Community Service (LPPM) University of Syiah Kuala and the members of the research team who supported the implementation of this research.

\section{REFERENCES}

Anderson, W.B., Seager, R., Baethgen, W., Cane, M., You, L., 2019. Synchronous crop failures and climate-forced production variability. Science Advances 5 , eaaw1976. https://doi.org/10.1126/sciadv.aaw1976

Birkinshaw, S.J., Guerreiro, S.B., Nicholson, A., Liang, Q., Quinn, P., Zhang, L., He, B., Yin, J., Fowler, H.J., 2017. Climate change impacts on Yangtze River discharge at the Three Gorges Dam. Hydrology and Earth System Sciences 21, 1911.

Bolota, I., Soetopo, W., Putra, S.M.B., 2016. Studi Optimasi Pola Operasi Waduk Krueng Seulimeum Kecamatan Seulimeum Kabupaten Aceh Besar. 
Chinwendu, O.G., Sadiku, S., Okhimamhe, A., Eichie, J., 2017. Households vulnerability and adaptation to climate variability induced water stress on downstream Kaduna River Basin. American Journal of Climate Change 6, 247-267.

Deo, R.C., Tiwari, M.K., Adamowski, J.F., Quilty, J.M., 2017. Forecasting effective drought index using a wavelet extreme learning machine (WELM) model. Stochastic Environmental Research and Risk Assessment 31, 1211-1240. https://doi.org/10.1007/s00477-016-1265-z

Evariani, E., 2018. Analisis Dampak Rehabilitasi Jaringan Irigasi Tersier Terhadap Pendapatan Petani Di Kabupaten Aceh Besar. Agrifo: Jurnal Agribisnis Universitas Malikussaleh 3, 55-63.

Farhan, A., Wardah, 2014. Keterkaitan hujan di Nanggo Aceh Darussalam gengan suhu muka lautan India dan Pasifik; (Bahagian dari upaya mitigasi dampak kekurangan air pada budidaya padi), in: Prosiding Seminar Hasil Penelitian 2014 LPPM Unsyiah.

Fuadi, N.A., Purwanto, M.Y.J., Tarigan, S.D., 2016. Kajian kebutuhan air dan produktivitas air padi sawah dengan sistem pemberian air secara sri dan konvensional menggunakan irigasi pipa. Jurnal Irigasi 11, 23-32.

Gao, Q.-G., Sombutmounvong, V., Xiong, L., Lee, J.-H., Kim, J.-S., 2019. Analysis of Drought-Sensitive Areas and Evolution Patterns through Statistical Simulations of the Indian Ocean Dipole Mode. Water 11. https://doi.org/10.3390/w11061302

Hendrawan, I.G., Asai, K., Triwahyuni, A., Lestari, D.V., 2019. The interanual rainfall variability in Indonesia corresponding to El Niño Southern Oscillation and Indian Ocean Dipole. Acta Oceanol. Sin. 38, 57-66. https://doi.org/10.1007/s13131-019-1457-1

Hidayat, A.M., Efendi, U., Agustina, L., Winarso, P.A., 2018. Korelasi Indeks Nino 3.4 dan Southern Oscillation Index (SOI) dengan Variasi Curah Hujan di Semarang. Jurnal Sains \& Teknologi Modifikasi Cuaca 19, 75-81.

Hidayat, R., Ando, K., 2014. Variabilitas curah hujan Indonesia dan hubungannya dengan enso/iod: estimasi menggunakan data jra-25/jcdas. Agromet 28, 1-8.

Ilhamsyah, Y., Farhan, A., Irham, M., Setiawan, I., Haditiar, Y., 2019. Greater Aceh, Indonesia Enters Climate Change: Climate on Extreme ENSO 2015-2016. Presented at the IOP Conference Series: Earth and Environmental Science, IOP Publishing, p. 012002.
Jadmiko, S.D., Faqih, A., 2014. Dynamical Downscaling Luaran Global Climate Model (GCM) Menggunakan Model REGCM3 untuk Proyeksi Curah Hujan di Kabupaten Indramayu. Agromet 28, 9-16.

Kim, J.-S., Jeong, S.-J., Kug, J.-S., Williams, M., 2019. Role of Local Air-Sea Interaction in Fire Activity Over Equatorial Asia. Geophysical Research Letters 46, 14789-14797. https://doi.org/10.1029/2019GL085943

Kosovelj, K., Kucharski, F., Molteni, F., Žagar, N., 2019. Modal decomposition of the global response to tropical heating perturbations resembling MJO. Journal of the Atmospheric Sciences 76, 1457-1469.

Krishnaswamy, J., Vaidyanathan, S., Rajagopalan, B., Bonell, M., Sankaran, M., Bhalla, R.S., Badiger, S., 2015. Non-stationary and non-linear influence of ENSO and Indian Ocean Dipole on the variability of Indian monsoon rainfall and extreme rain events. Clim Dyn 45, 175-184. https://doi.org/10.1007/s00382-014-2288-0

Lestari, S., King, A., Vincent, C., Karoly, D., Protat, A., 2019. Seasonal dependence of rainfall extremes in and around Jakarta, Indonesia. Weather and Climate Extremes 24, 100202. https://doi.org/10.1016/j.wace.2019.100202

Misnawati, ., Perdanawanti, M., 2019. Trend of Extreme Precipitation over Sumatera Island for 19812010. J.Agromet 33, 41-51. https://doi.org/10.29244/j.agromet.33.1.41-51

Mulyaqin, T., 2020. The Impact of El Niño and La Nina on Fluctuation of Rice Production in Banten Province. Agromet 34, 34-41.

Nabilah, F., Prasetyo, Y., Sukmono, A., 2017. Analisis pengaruh fenomena El Nino dan La Nina terhadap curah hujan tahun 1998-2016 menggunakan indikator ONI (Oceanic Nino Index)(studi kasus: Provinsi Jawa Barat). Jurnal Geodesi Undip 6, 402-412.

Nasrullah, N., Kartiwa, B., 2010. Analisis alih fungsi lahan dan keterkaitannya dengan karakteristik hidrologi DAS Krueng Aceh. J. Tanah dan Iklim 31, 81-98.

Nurdiansyah, L., Faqih, A., 2018. Forecasting Season Onsets in Kapuas District Based on Global Climate Model Outputs. Agromet 32, 1-10.

Pan, X., Chin, M., Ichoku, C.M., Field, R.D., 2018. Connecting Indonesian Fires and Drought With the Type of El Niño and Phase of the Indian Ocean Dipole During 1979-2016. Journal of Geophysical Research: Atmospheres 123, 7974-7988. https://doi.org/10.1029/2018JD028402 
Prasetyo, B., Pusparini, N., 2018. Pengaruh Central Pacific dan eastern Pacific El Nino terhadap variabilitas curah hujan di Sulawesi. Jurnal Sains Dirgantara 15, 73-84.

Purnama, D.I., 2019. Analisis Komponen Utama Pada Data Potensi Kecamatan di Kota Palu Sebelum Bencana Gempa Bumi dan Tsunami 28 September 2018. Jurnal Matematika, Statistika dan Komputasi 16, 25-32.

Qalbi, H.B., Faqih, A., Hidayat, R., 2017. Future rainfall variability in Indonesia under different ENSO and IOD composites based on decadal predictions of CMIP5 datasets. Presented at the IOP Conference Series: Earth and Environmental Science, IOP Publishing, p. 012043.

Rufaidah, A., Effindi, A., 2017. Analisis Komponen Utama Pada Penerapan Aplikasi Pembelajaran Metode Glenn Doman. Jurnal Ilmiah Edutic 3, 107-112.

van Delsen, M.S.N., Wattimena, A.Z., Saputri, S., 2017. Penggunaan Metode Analisis Komponen Utama untuk Mereduksi Faktor-faktor Inflasi di Kota Ambon. BAREKENG: Jurnal Ilmu Matematika dan Terapan 11, 109-118.

van den Besselaar, E.J.M., van der Schrier, G., Cornes, R.C., Iqbal, A.S., Klein Tank, A.M.G., 2017. SAOBS: A Daily Gridded Surface Temperature and Precipitation Dataset for Southeast Asia. J.
Climate 30, $5151-5165$. https://doi.org/10.1175/JCLI-D-16-0575.1

Windari, E.H., Faqih, A., Hermawan, E., 2012. El nino modoki dan pengaruhnya terhadap perilaku curah hujan monsunal di Indonesia. Jurnal Meteorologi dan Geofisika 13.

Yananto, A., Dewi, S., 2016. Analisis kejadian el nino tahun 2015 dan pengaruhnya terhadap peningkatan titik api di wilayah Sumatera dan Kalimantan. Jurnal Sains \& Teknologi Modifikasi Cuaca 17, 11-19.

Zhang, Q., Wang, H., Dong, J., Zhong, G., Sun, X., 2017. Prediction of Sea Surface Temperature Using Long Short-Term Memory. IEEE Geoscience and Remote Sensing Letters 14, 1745-1749. https://doi.org/10.1109/LGRS.2017.2733548

Zhao, D., Li, Y.-R., 2015. Climate Change and Sugarcane Production: Potential Impact and Mitigation Strategies. International Journal of Agronomy, 547386 10. http://dx.doi.org/10.1155/2015/547386

Zhao, Y., Zou, X., Gao, J., Xu, X., Wang, C., Tang, D., Wang, T., Wu, X., 2015. Quantifying the anthropogenic and climatic contributions to changes in water discharge and sediment load into the sea: A case study of the Yangtze River, China. Science of The Total Environment 536, 803-812. https://doi.org/10.1016/j.scitotenv.2015.07.11 9 